\title{
Psychological Competence of Educator as a Prerequisite of Effective Developmental Interaction with Students
}

\section{Психологічна компетентність викладача як передумова ефективної розвивальної взаємодії зі студентами}

\section{Oksana Furman (Humeniuk)}

Dr. in Psychology, Professor, Professor of the Department of Psychology and Social Work, Ternopil National Economic University, Ternopil (Ukraine)

ORCID ID: https://orcid.org/0000-0002-7082-9717

E-mail: anatoliy_furman@yahoo.com

\section{Оксана Фурман (Гуменюк)}

Доктор психологічних наук, професор, професор кафедри психології та соціальної роботи, Тернопільський національний економічний університет, м. Тернопіль (Україна)

\section{Andriy Hirnyak}

Ph.D. in Psychology, Assistant Professor, Assistant Professor of the Department of Psychology and Social Work, Ternopil National Economic University, Ternopil, (Ukraine)

ORCID ID: https://orcid.org/0000-0003-3854-4866

E-mail: girand@ukr.net

\section{Андрій Гірняк}

Кандидат психологічних наук, доцент, доцент кафедри психології та соціальної роботи, Тернопільський національний економічний університет, м. Тернопіль (Україна)

Address for correspondence, e-mail: kpnu_lab_ps@ukr.net Copyright: (C) Furman (Humeniuk) Oksana, Hirnyak Andriy

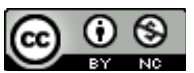
The article is licensed under CC BY-NC 4.0 International (https://creativecommons.org/licenses/by-nc/4.0/)

(C) Furman (Humeniuk) Oksana, Hirnyak Andriy DOI (article): https://doi.org/10.32626/2227-6246.2020-50.236-266 http://journals.uran.ua/index.php/2227-6246 
DOI: https://doi.org/10.32626/2227-6246.2020-50 2020. випуск 50

The contribution of the author: Furman (Humeniuk) O. - 50\%, Hirnyak A. $50 \%$.

Авторський внесок: Фурман (Гуменюк) О. - 50\%, Гірняк А. - 50\%.

\section{ABSTRACT}

The purpose of our article is to substantiate theoretically and prove empirically that the level of psychological competence of educators-researchers influences significantly on the quality of organization and effectiveness of full-fledged developmental interaction with the students in modern Institution of Higher Education.

Methods of the research. The authors used theoretical methods of cognition (critical analysis, theoretical synthesis, ranking, abstraction, criterion comparison, methodological generalization, theoretical modeling, etc.), as well as empirical methods of factual data recording (closed questionnaire, psychological and pedagogical experiment, psycho-diagnostic techniques: the questionnaire "Who will pick up the paper?» by A. Furman, the "Self-Actualization Test» (SAT) by E. Shostrom etc.). 65 teachers and 511 undergraduate students (1-4 years of studying) of the Faculty of Law of Ternopil National Economic University (TNEU) were involved in the experiment started in September, 2017 and finished in September, 2019.

The results of the research. This article outlines the current tasks and innovative ways to improve the psychological training of educators of modern Institutions of Higher Education, in particular, reveals the authors' experience in implementing the training program of educator-psychologist-researcher $(690$ hours), that is accompanied by the increasing of expert-mental conditions in the teaching staff's innovative activity; five groups of experimental changes (innovations), which led to the positive restructuring of the educator-researchers' inner world, are characterized; the growth dynamics of psychological competence of educators of the Faculty of Law of TNEU is being observed experimentally for two years of fundamental experiment; the total coefficient growth of the educator-researchers' self-actualization is empirically substantiated on 13 scales of measurements. The obtained quantitative indicators convince clearly that both total indicator of the coefficient of self-actualization of the faculty teaching staff (from 43.2\% to 48.8\%) and its structural components (rapport - 9\%, self-acceptance $-7.7 \%$, flexibility of behavior $-7.5 \%$, synergy $-7.3 \%$, sensitivity $-6.2 \%$, spontaneity $-6.0 \%$, etc.) have significantly increased for two years of fundamen-

(C) Furman (Humeniuk) Oksana, Hirniak Andriy DOI (article): https://doi.org/10.32626/2227-6246.2020-50.236-266 
tal experimentation. The fact of increasing tendencies to self-realization of educators due to the basic scales of time competence and support, the total growth of which is $15.6 \%$, is particularly positive.

Conclusions. The modular developmental system of education has a number of advantages in comparison with the classical academic system. In particular, it enables the training of educators for professional activity with psychological and pedagogical content of the current educational process and due to the appropriate technologies it allows the more thoroughly implementation of the multilevel developmental interaction with students in the practice of modern Institution of Higher Education. The effectiveness of this interaction primarily depends on the psychological literacy of an educator, the humanization of tasks, the content and style of educational activities and the implementation of original technologies for a holistic modular developmental process conducting. The qualitatively higher professional and psychological training of an educator can be achieved when the educational process center is not the content of studying, but the interaction of mentor and student, that does not only humanize the educational environment, but also predicts the position changes of each subject of relevant relationships. The integral psychometric indicator of the development of culture and educator-researchers functional literacy is the coefficient of self-actualization, the growth of which indicates a significant boundaries expansion of the constructive expression of freedom, altruism, creativity, self-esteem, persons' mutual understanding and mutual acceptance in the individually oriented educational process.

Key words: modular developmental system, psychological competence, developmental interaction, social and psychological experiment, educational module stages, self-actualized personality.

\section{Introduction}

The interaction is one of the most typical processes of a socialized person, who enters alternately into subject-object relationships and influences at the levels of separate individuals, groups or communities. The civilization itself emerged due to the interpersonal communication and the vital-cultural experience transmission through the intergenerational exchange, imitation of cultural standards and patterns of behavior. It is obviously that the socialization of youth always required the (C) Furman (Humeniuk) Oksana, Hirnyak Andriy

DOI (article): https://doi.org/10.32626/2227-6246.2020-50.236-266 
effective group forms, poly-dialogical methods and interactive techniques in the system of "successor - mentor», as one of the key functions of the institute of education. The parity interaction and partnership is the essential core of educational environment, which promotes the personal development, professional growth and self-realization of each student. In turn, the effectiveness of multi-channel developmental interaction depends primarily on the proper functional competence and the level of psychological culture of a professional educator who works in a qualitatively different socio-cultural situation. It requires the educator's special ability to differentiate professionally and work effectively with the socio-psychological content of the main stages of holistic educational cycle.

Numerous foreign and Ukrainian scientists in their scientific researches covered various aspects of the issue: the essential features and characteristics of psycho-developmental interaction in the context of personality-oriented approach (M. Skrypnyk (Skrypnyk, 2012), I. Ziaziun (Ziaziun, 2011), V. Rybalka (Rybalka, 1998) and others), the behavior models and styles of pedagogical communication (V. Kan-Kalyk (KanKalyk, 1987), O. Leontiev (Leontiev, 1997), Ye. Rohov (Rohov, 2004), the development of organization forms of psycho-developmental interaction in the educational process (V. Andreiev (Andreiev, 2019), O. Shtepa (Shtepa, 2011) and others), the study and characterization of pedagogical activity subject (B. Bratus (Bratus, 1997), A. Brushlynskyi (Brushlynskyi, 2003)), the development of facilitating educator position (K. Rogers (Rogers, 2007)), features of dialogic interaction establishing (H. Ball (Ball, 2011), I. Bekh (Bekh, 1998), V. Bibler (Bibler, 2015)), psychological and pedagogical conditions and requirements for the organization of effective interaction of educators and students (Sh. Amonashvili (Amonashvili, 1996), Yu. Babanskyi (Babanskyi, 1989), I. Bulakh (Bulakh, 2002) and others), the pedagogical ethics issues of educators and students' interaction (I. Bekh (Bekh, 2012), A. Kalenskyi

(C) Furman (Humeniuk) Oksana, Hirniak Andriy DOI (article): https://doi.org/10.32626/2227-6246.2020-50.236-266 
(Kalenskyi, 2013), the educator's training for pedagogical interaction (L. Velytchenko (Velytchenko, 2013), O. Matviienko (Matviienko, 2010) and others).

Our scientific researches on the psychological patterns of developmental interaction in the educational process are centered on the various aspects of the modular developmental system of education. This system is scientifically and methodologically substantiated and organizationally and technologically tested due to the scientific school of professor A. Furman (Furman, 1997, 2019) who is the author and ideological inspirer of a number of original projects and program researches on solving different educational problems: the creation of innovative and psychological climate and the development of positive and harmonious Self-concept (O. Furman (Furman, 2008, 2015), M. Lypka (Lypka, 2018)), the development of reflection, tolerance and spiritual potential of a person (Ya. Bugerko (Bugerko, 2009), O. Shaiuk (Shaiuk, 2017), the realization of creative intentions and creativity of the youth (S. Shandruk (Shandruk, 2015), V. Demkiv (Demkiv, 2019)), the optimal psychological technologies of adaptation (I. Revasevych (Revasevych, 2018)), conditions of the effective socialization and formation of personality (A. Furman (Furman, 2009), M. Bryhadyr (Bryhadyr, 2013)), the design of modern educator's psycho-didactic tools (H. Hirnyak (Hirnyak, 2014), A. Hirnyak, T. Kozlova (Kozlova, 2014)), the newest aspects of psycho-diagnostics and psychological expertise (A. Furman (Furman, 2002), L. Rebukha (Rebukha, 2011)), the actual problems of tasks designing and psychological service work (T. Nadvynychna (Nadvynychna, 2012)), the experience and scientific results of fundamental socio-psychological experiment on the introduction of modular developmental system of education in the educational process of domestic educational institutions (V. Komissarov (Komissarov, 2007), Ya. Kostin (Kostin, 2007) and others).

However, the problem of effective system establishing for improving the psychological competence of educator of the In(C) Furman (Humeniuk) Oksana, Hirnyak Andriy

DOI (article): https://doi.org/10.32626/2227-6246.2020-50.236-266 
stitution of Higher Education remains unresolved, which led us to choose this topic.

The purpose of our article is to substantiate theoretically and prove empirically that the level of psychological competence of educators-researchers influences significantly on the quality of organization and effectiveness of the full-fledged developmental interaction with the students in modern Institution of Higher Education.

\section{The tasks of the research}

1. To substantiate theoretically the main groups of experimental conditions (innovations), which cause the educator's psychological competence increase and enable his projective training as a mentor-psychologist-researcher.

2. To prove empirically the effectiveness of the author's program, which is developed on the basis of mentioned experimental conditions, aimed at the educator's preparing for professional activities with psychological and pedagogical content of current educational process that humanizes the educational environment and determines the multilevel developmental interaction with students.

\section{Methods of the research}

For the progressive tasks solution the authors used the comparative analysis of traditional and innovative models of educational process (Knysh, 2020), the theoretical synthesis of the latest technologies essence of developmental interaction in the system of "educator - students" (Burkhanova, 2020), the methodological generalization of the advanced psychological and pedagogical experience of practical implementation of the innovative developments in the Institutions of Higher Education (Luterbach, 2018; Boller, 2017), the hierarchization of classes of socio-psychological influence, theoretical modeling of the content aspects of the developmental interaction

(C) Furman (Humeniuk) Oksana, Hirniak Andriy DOI (article): https://doi.org/10.32626/2227-6246.2020-50.236-266 
(psychological and pedagogical, educational, methodical and meaningful, managerial and technological) (Maicon da Silva, 2020), the criterion differentiation of five groups of experimental conditions (innovations), which ensure the growth of educator's psychological competence, the reflection of experiment results on the modular developmental system implementation in several dozen of primary schools (the State Academy of Management Education) and Institutions of Higher Education of Ukraine; the theoretical abstraction and generalization of form and content advantages of the experimental modular developmental system.

During the research, authors used the empirical methods of factual data recording. In particular, it was used a closed questionnaire of educators and students as the subjects of educational interaction; it was conducted a psychological and pedagogical experiment; and there were used a number of psycho-diagnostic methods: the questionnaire "Who will pick up a piece of paper?» by A. Furman, the self-actualization test (SAT) by E. Shostrom. 65 educators and 511 undergraduate students (1-4 years of studying) of the Faculty of Law of Ternopil National Economic University (TNEU) were involved in the experiment, from September, 2017 to September, 2019.

\section{Results and the discussion}

According to the innovative modular developmental system of education (Furman, 1997; Humeniuk, 1998), the developmental interaction is the main consolidating factor of effective educational activities of educators and students. This is possible due to a single socio-psychological content of the holistic functional cycle stages of educational module, which puts each subject of educational interaction in the position of recipient and carrier of advanced cultural experience during the parity-dialogue relations. The effectiveness of these stages is mainly determined by which individuals enter the process of mutual exchange, e.g. their attitudes, abilities, character, (c) Furman (Humeniuk) Oksana, Hirnyak Andriy

DOI (article): https://doi.org/10.32626/2227-6246.2020-50.236-266 
value-semantic aspirations and other psychological properties-intentions are inherent in the mentor and successor. It is obviously that the effectiveness of developmental interaction depends largely on the level of educator's psychological literacy, his willingness and ability to offer the optimal ways and methods to overcome the problematic pedagogical situations. For this purpose, we studied the professional and personal competence of educators of the Faculty of Law of the Ternopil National Economic University (TNEU) with the help of two psycho-diagnostic tools: 1) the questionnaire «Who will pick up the paper?» by A. Furman (Furman, 2002), which, by methods of problem-situational diagnostics, allows determining the quality of educator's psychological preparation; 2) the questionnaire by E. Shostrom (Gozman, 1995), which is developed on the conceptual principles of humanistic psychology and helps to establish the objective value of an individual to self-actualization by the fourteen parameters.

To conduct the socio-psychological experiment, we proposed a training program for educators-psychologists-researchers (690 hours), as a part of proficiency enhancement, which provides a highly professional level of methodological and psychological culture of an educator, as a key executor of the experimental tasks. The full cycle of program implementation was structurally provided by the author of the article as a coordinator of scientific and methodical work of the Faculty of Law of TNEU and has lasted for two years. Thus, from September, 2017 to September, 2019, 65 educators passed the appropriate retraining, which included a course of author's lectures, system of practice trainings, group and individual consultations of the educators, round tables, seminars and open modular developmental classes by lecturers of the Department of Psychology and Social Work. The main results of this work: each educator-practitioner has mastered ten psycho-diagnostic techniques, learned to conduct the initial quantitative processing of test data (Hirnyak, 2019), studied the strategy, tactics and

(C) Furman (Humeniuk) Oksana, Hirniak Andriy DOI (article): https://doi.org/10.32626/2227-6246.2020-50.236-266 
DOI: https://doi.org/10.32626/2227-6246.2020-50 2020. випуск 50

technique of innovative psychological and pedagogical technologies, received the professional skills of multilevel motivation for students' educational and professional activity and human principles of implementation of the individual approach to young people, as well as mastered the skills of psycho-creative design for the newest psychologically effective software and methodological support, etc.

Thus, the first group of experimental changes that affected significantly the inner world of the educator, concerns his qualitatively higher professional and psychological training, when the educational process center is not the content of the subject, but the interaction of educator and student, a new pedagogical ethic, which does not only humanize the educational environment, but also involves changing of one's own position, the experience of parity relationships, the increasing weight of personal communication, motivation for creative search, modeling of life situations.

The second group of experimental changes relates to the tasks, content and nature of educator and students' educational activities in which all participants in the educational process: a) focus on obtaining and disseminating the best socio-cultural experience of nation and humanity; b) perform the identical socio-psychological functions at each stage of the modular development process; c) differ in parity contacts by civic, professional and personal experience; d) are socially equal participants in dialogical interaction, continuous productive search for various components of experience; e) use innovative software and methodological tools (graphs, research projects, modular developmental textbooks, educational programs of self-realization, etc.) that optimize their exchange and psycho-social growth; f) are guided in the same way as the external management guidelines and recommendations, and the internal tools (methods, techniques, algorithms, etc.) of self-management, and reflections on the effectiveness of their own educational activities (Hirnyak, 2018; Furman, 2015).

(C) Furman (Humeniuk) Oksana, Hirnyak Andriy

DOI (article): https://doi.org/10.32626/2227-6246.2020-50.236-266 
The third group of experimental changes reflects approaches to design and implementation of the innovative technologies for conducting a holistic modular development process, which radically changes the ways of educational process managing, because: a) the primary importance in a modular lesson is psychological and pedagogical content and emotional and psychological atmosphere of developmental interaction; b) the secondary role is played by the specific educational technology, which corresponds to one or another stage of the modular developmental process (sensory aesthetic, instructional and motivational, theoretically-meaningful, evaluative-conceptual, adaptive-transforming, system-generalizing, control-reflexive, spiritually-aesthetic and spontaneously-creative); c) the auxiliary or derivative functions are performed by forms, methods and tools of joint educational activity of an educator and a student, which are selected at their discretion depending on the situation, features of psychological and pedagogical content and the own motives for the search activity; d) the resulting aspect is the effectiveness of developmental interaction, which guarantees the full realization of the best intellectual and social potential of an individual (Furman, 2019; Humeniuk, 2008).

The fourth group of experimental changes concerns motives and values of the participants of developmental interaction: a) the educator's desire to improve himself, his methodological and psychological literacy; b) the students' desire to seek solutions to social scientific problems during the common educational activities, satisfaction from psychologically equal cooperation with educator; c) the inalienable value of interpersonal interaction, which is supported by adults as a current, nationally significant, socio-cultural experience (Humeniuk, 2008; Nilson, 2016).

The fifth group of experimental changes fixes the nomenclature of innovative software tools (graphs, research projects, modular development mini-textbooks, etc.), which are a com-

(C) Furman (Humeniuk) Oksana, Hirniak Andriy DOI (article): https://doi.org/10.32626/2227-6246.2020-50.236-266 
DOI: https://doi.org/10.32626/2227-6246.2020-50 2020. випуск 50

plex tool for managing and self-managing of the developmental interaction. Educators and students, while working with these tools, implement the acceptable for their age and individual features trajectory of psycho-social development, which tactically runs from cognitive and informational innovations to legal-regulatory and value-aesthetic.

It is obviously that these experimental changes affected the qualitative growth of psychological literacy of the educators of the Faculty of Law of TNEU, which is confirmed by the problem-situational diagnosis that had been conducted annually since 2017 according to the questionnaire «Who will pick up the paper?» (See Table 1). The author of the method differentiates cultural and psychological literacy of the educator into three types: 1) professional awareness (low, very low and extremely low levels); 2) pedagogical competence (intermediate level and above / below average); 3) psychological and pedagogical skills (exceptionally high, very high and high levels) (Furman, 2002). The obtained quantitative indicators show clearly that in two years of the experiment there is an increase in the level of psychological competence of professors and educators, especially in the range between 2018 and 2019. The evidence here is in the results of certification, research and experimental, design and methodological work of each member of the teaching staff.

Thus, according to the survey of educators, 96\% noted the positive changes in themselves, the increased productivity in modular developmental training, and $75 \%$ of respondents indicated the increase of students' independence in classroom, which contributed to mutual evaluation, reflection, advanced tasks and creative approaches to lectures and seminars. Among the success of work with the academic group the educators noted the growth of motivation and cognitive activity of students, the greater opportunities for creative collaboration with youth, and better understanding of the future specialist's individuality.

(C) Furman (Humeniuk) Oksana, Hirnyak Andriy

DOI (article): https://doi.org/10.32626/2227-6246.2020-50.236-266 
ISSN 2227-6246 (Print)

ISSN 2663-6956 (Online)

ПРОБЛЕМИ СУЧАСНОЇ ПСИХОЛОГІЇ

DOI: https://doi.org/10.32626/2227-6246.2020-50

2020. ВИПУСК 50

$\frac{1}{0}$

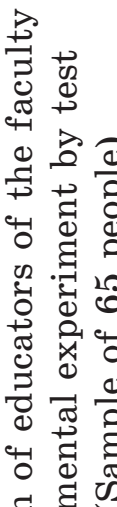

공

完

क्षे

>

का

है फ 0

$\because \begin{array}{lll} \pm & 0 & 0\end{array}$

శ

บ $\overbrace{2}^{\circ}$

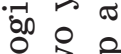

응

है

है

은

है

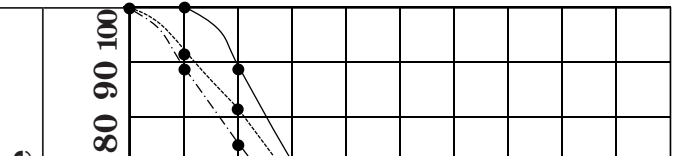

寻

学定

已 स

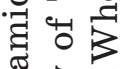

胥 3

坣

엉

E
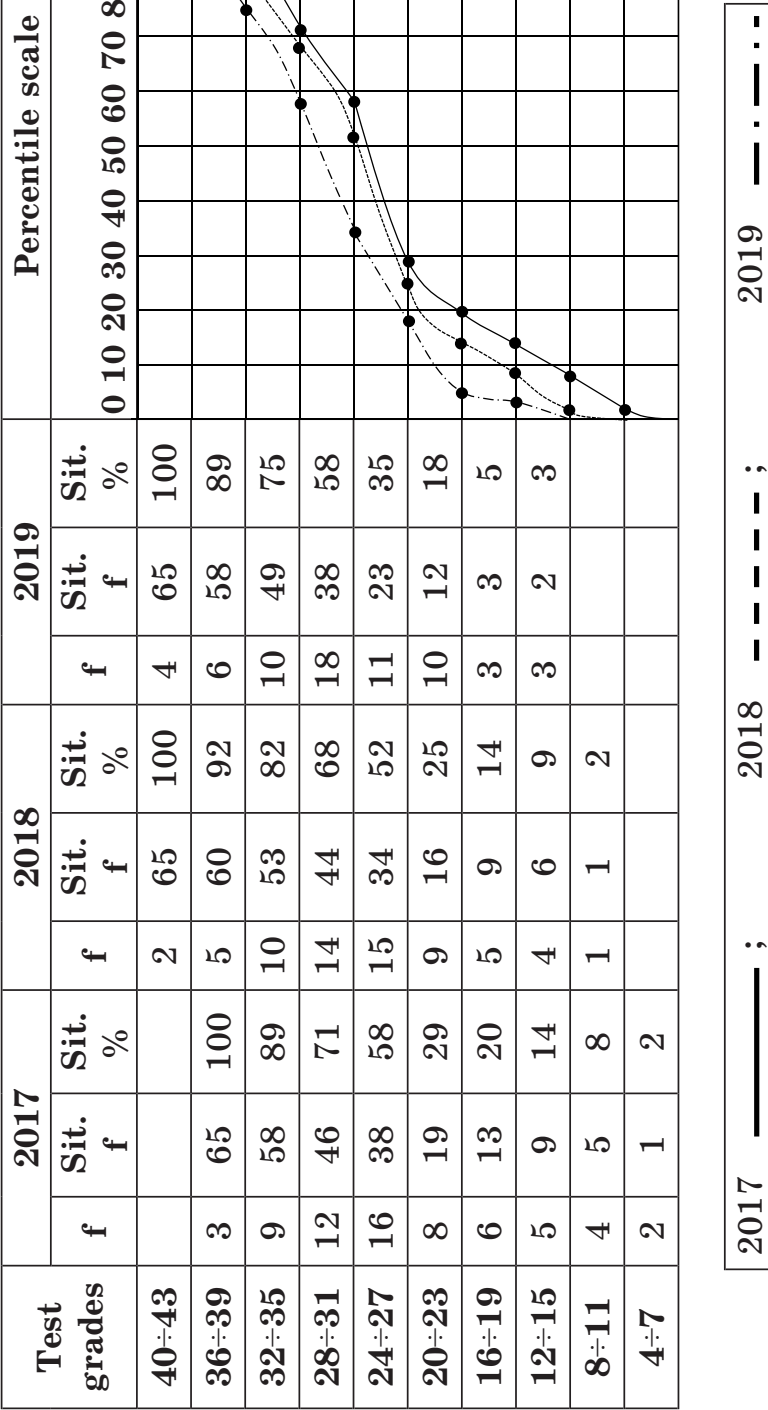

(C) Furman (Humeniuk) Oksana, Hirniak Andriy DOI (article): https://doi.org/10.32626/2227-6246.2020-50.236-266 
DOI: https://doi.org/10.32626/2227-6246.2020-50 2020. випуск 50

At the same time, we interviewed 511 undergraduate students (1-4 years of studying) of the faculty of law of TNEU. $81.6 \%$ of the first-year students wrote in a questionnaire that they liked to study at this faculty, $62.7 \%$ would agree to come for informal communication, even in extracurricular activities, and $76.4 \%$ did not want to reduce the demands of educators. Among the second- and third-year students, no one considers their faculty bad, and for almost $72 \%$ - it is the best. It is noteworthy that more than $97 \%$ of students associate their success in one or another discipline with the professional skills of the educator. The main thing in the mentor, for them, is the friendliness and desire to achieve mutual understanding $(61 \%)$, excellent knowledge of the subject (81\%), patience $(35 \%)$, fairness and objectivity $(84 \%)$.

The most tangible factor in the growth of scientific and psychological culture of educators was their innovative activities to design a new educational and methodological support of the experimental system of education. Thus, during 20172019 the professors and educators of the faculty of law of TNEU had developed the author's graphs of training courses and modular developmental textbooks for basic disciplines, which demonstrate a creative potential of the teaching staff (Furman, 2019). As for the students of the faculty of law of TNEU, during 2017-2019, there were 15 winners (9 and 6 respectively) of the second round of All-Ukrainian Olympiads and competitions of student research papers only at the Department of Psychology and Social Work. Some of them have already become the official experts of the National Agency for Quality Assurance in Higher Education on accreditation of specialized educational programs.

Thus, a significant increase in psychological literacy of educators of the faculty of law of TNEU is based on a deep and comprehensive orientation in the inner world of students, the ability to capture the uniqueness and diversity of the future specialist's individuality, based on scientific tools of know(C) Furman (Humeniuk) Oksana, Hirnyak Andriy

DOI (article): https://doi.org/10.32626/2227-6246.2020-50.236-266 
ledge and transformation of the environment. As a result, the educator does not only master the art of psychological justification of optimal pedagogical decisions, but also acquires the basic competencies to act better in any problem situation, contextually implementing a unique way that maximally stimulates the student's cultural development at this time and in specific circumstances.

The humanistic orientations of modular developmental education are clearly confirmed in the research of self-actualization level of educators of the faculty of law of TNEU by the well-known method of E. Shostrom, which is created on the conceptual basis of Abraham Maslov's theory of self-actualized personality (Gozman, 1995). The popularity of this theory is mainly due to the discovery of positive potential of human nature in creativity, altruism, freedom, friendship, love and others. They appear as a kind of standards in the process of citizen education and establishing a developmental relationship between the educator and student.

Since the concept of self-actualization is characterized by multiple content, which involves the comprehensive development of creative and social potential of a person, the maximum situational realization of his positive potential, the adequate perception of others, the world and his place in it, the richness of emotional sphere and spiritual self-activity, a high mental health and morality, that's why the Shostrom's method is based on the principles of multidimensional description of the phenomenon of self-actualization. Thus, 126 items of the questionnaire, each of them contains the choice of two judgments of value or behavioral nature, are organized into 14 scales two basic ( «temporal competence», "support») and twelve additional. The table 2 shows the survey results of educators of the Faculty of Law of TNEU at the beginning of the experiment and after its completion. Socio-psychological analysis of these results allows us drawing the following conclusions:

(C) Furman (Humeniuk) Oksana, Hirniak Andriy DOI (article): https://doi.org/10.32626/2227-6246.2020-50.236-266 
Results summary of the averaged data on the level of personal self-actualization of educators of the Faculty of Law of TNEU in September, 2017 and September, 2019 on 14 scales by the E. Shostrom's method (sample of 65 people)

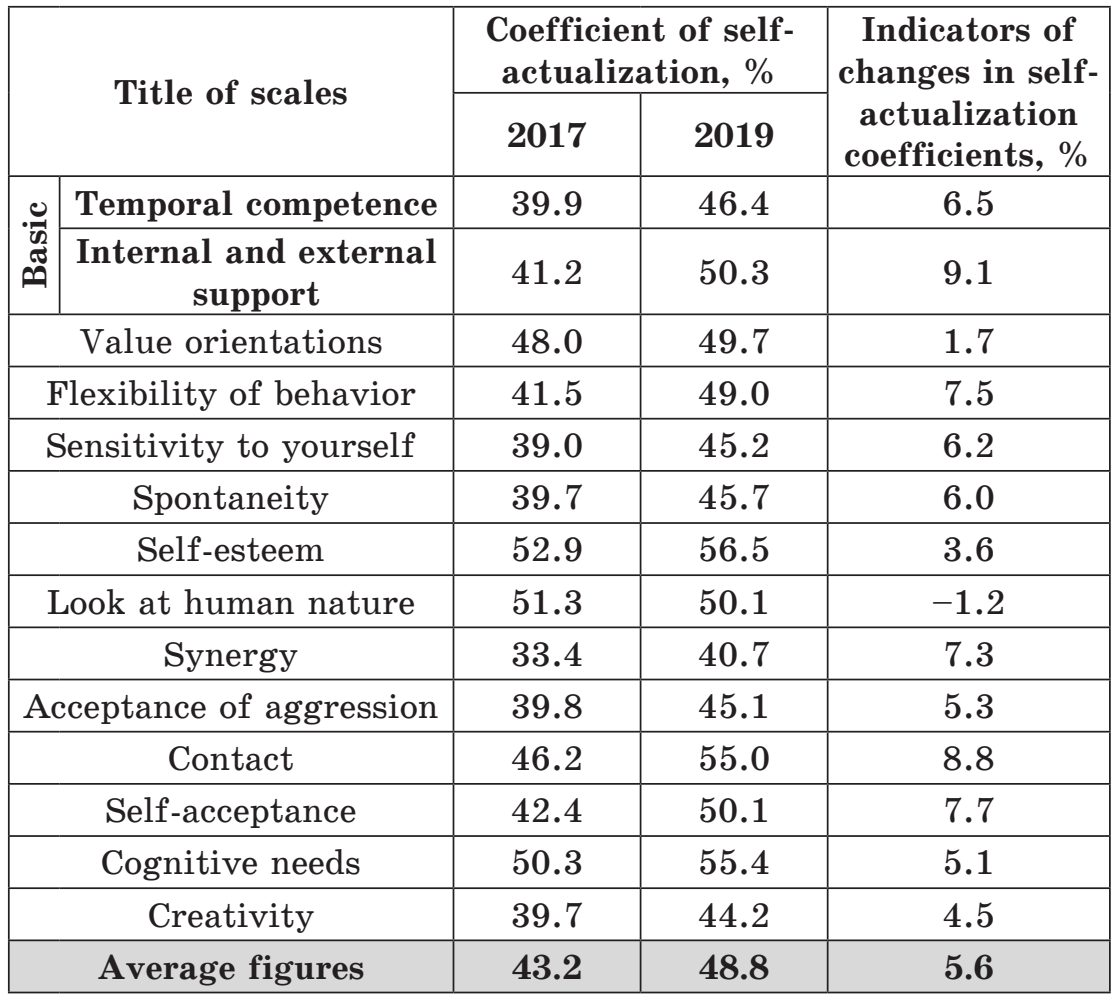

Firstly, for two years of fundamental experimentation, both the total indicator of coefficient of the educators' self-actualization (from $43.2 \%$ to $48.8 \%$ ) and its structural components that characterize more or less growth of thirteen scale indicators of individual desire to self-realization. The fact of increasing tendencies to self-realization of educators of the (C) Furman (Humeniuk) Oksana, Hirnyak Andriy

DOI (article): https://doi.org/10.32626/2227-6246.2020-50.236-266 
Faculty of Law on the basic scales of time competence and support is particularly positive as the total growth of this coefficient is $15.6 \%$. In the context of this research, it means that each educator has acquired the ability to experience better the everyday moments of his life, to feel more sharply the indivisibility of past, present and future, and became more independent in their actions and, accordingly, in thoughts, beliefs, principles. All this contributed to the expansion of the field of internal freedom and independence of individual behavior from the environment in a situation of supporting cultural norms of social activity, which is crucial in organizing the developmental interaction of educators with students as his psychological willingness to interact and create a constructive educational environment.

Secondly, there is a significant increase, except the basic scales, in the coefficient of self-actualization by nine additional ones: the contactness - by $\mathbf{9 . 0 \%}$ (a person's ability to establish warm emotional relationships with other people quickly); self-acceptance - by 7.7\% (a human understanding of oneself, which is actually beyond the assessment of his own strengths and weaknesses); flexibility of behavior - by $7.5 \%$ (the ability to respond quickly and adequately to any situational changes); synergy - by $7.3 \%$ (the ability for holistic perception of the world and people, understanding the unity of such contradictions as physical and spiritual, play and work, etc.); sensitivity $-6.2 \%$ (a personal self-awareness of his needs and feelings, the ability to anticipate); spontaneity $-6.0 \%$ (the ability to naturally express feelings, be direct, open); the acceptance of aggression - by $5.3 \%$ (the ability of an individual to accept his irritation and aggression as natural manifestations of human nature); the cognitive needs $-5.1 \%$ (activation of cognitive needs, the desire for productive thinking); creativity - by $4.5 \%$ (the realization of creative orientation of an individual). Obviously, the outlined set of mental properties is a necessary internal prerequisite for educator's organizing such socio-cul-

(C) Furman (Humeniuk) Oksana, Hirniak Andriy DOI (article): https://doi.org/10.32626/2227-6246.2020-50.236-266 
DOI: https://doi.org/10.32626/2227-6246.2020-50

tural relationships with students, which unfold and function in accordance with the laws of developmental cooperation, i.e. they are characterized by dialogue, poly-problem, social equality and humanity.

Thirdly, the indicators of two traditional scales - values and self-esteem - were not significantly changed. At the same time, the educators' views on human nature became slightly less optimistic $(-1.2 \%)$. It is most probable that the indicators of these diagnostic parameters are directly due to the tough socio-economic situation that has developed in the country today, and are not directly related to the influence of experimental conditions. Rather, on the contrary, the disappointing circumstances of the professional life of Ukrainian educators affect negatively the implementation of any constructive reform measures in the education system. Thus, the presented research results of socio-psychological literacy of the educators of Institutions of Higher Education give grounds to claim that modular developmental education in connection with innovative principles, technologies and methodological tools has a number of advantages over the classical academic system. In particular, this innovative system enables the pre-professional mentor's training with psychological and pedagogical content of the current educational process and with the help of appropriate technologies allows more thoroughly implementing the multilevel developmental interaction with students in the practice of modern higher level. The effectiveness of this interaction primarily depends on the psychological literacy of educator, the humanization of tasks, the content and style of educational activities, the implementation of original technologies for a holistic modular developmental process, the cultural reorientation of motivation and value spheres and skillful usage of innovative software. One of the key indicators of such ability is the coefficient of educator's self-actualization, which tends to grow steadily under the favorable conditions. 


\section{Conclusions}

1. The experiment for modular developmental system is possible if the educator of the Institution of Higher Education is trained as a professional psychologist and researcher and is able to solve the complex problems of scientific design and creative embodiment of the socio-psychological space of continuous developmental interaction in a particular academic group.

2. The psychological literacy content of the educator-researcher is primarily determined by the fundamental tests of intelligence, personality and creativity, the using technology of which, in the system of experimental education, involves the demarcation of goals, objectives, structure, forms, mechanisms and tools of parity educational activity of the educator and student at each stage of the modular developmental process.

3. The implementation of educator-psychologist-researcher training program (690 hours) should be accompanied with the experimental changes (conditions) increasing in the innovative activity of teaching staff (the humane pedagogical ethics, the cultural orientation of students' educational activity, the designing strategy and tactics of the full functional cycle of modular developmental process, the innovative techniques implementation of developmental interaction, a set of author's expert-diagnostic and software-methodical tools, etc.).

4. The problem-situational diagnosis of educators' professional abilities allows: a) determining the humanistic and psychological competence of each educator-researcher, b) studying the dynamics of person's psychological competence levels who has a steady tendency to increase the personal indicators, c) predicting the creative achievements of educators and the teaching staff in general in the creation of innovative software and methodological support of the educational process and in mastering the psycho-creation technologies of teaching.

5 . The coefficient of self-actualization is an integral psychometric indicator of the development of internal culture and

(C) Furman (Humeniuk) Oksana, Hirniak Andriy DOI (article): https://doi.org/10.32626/2227-6246.2020-50.236-266 
DOI: https://doi.org/10.32626/2227-6246.2020-50

2020. випУск 50

functional literacy of the educator-researchers, and the growth of which, in the modular developmental system, indicates a significant expansion of constructive expression of freedom, altruism, inspiration, faith, creativity, love, self-esteem, persons' mutual understanding and mutual acceptance in an individually oriented educational process.

The direction of further scientific researches on the mentioned issues will be the criterion selection of indicators of the educators' psychological competence and the study of correlations between the level of noticed professional characteristics of the educator and the effectiveness of training lessons.

\section{Literature}

Амонашвили Ш. А. Размышления о гуманной педагогике. Москва : Издательский дом Шалвы Амонашвили, 1996. 494 с.

Андрєєв В. Педагогічна взаємодія викладачів коледжу мистецького напрямку. Social work and education. 2019. № 6 (1). С. 80-86.

Бабанский Ю. К. Избранные педагогические труды: науч. изд. / сост. М. Ю. Бабанский. Москва : Педагогика, 1989. 560 с.

Бех I. Акценти мистецької творчості та виховання особистості. Ecmeтика і етика педагогічної дї. 2012. Вип. 3. С. 38-43.

Бех І. Д. Особистісно зорієнтоване виховання: наук.-метод. посіб. Київ : I3MH, 1998. 204 c.

Біблер В. Діалог культур. Філософія. Психологія і суспільство. 2015. № 3. С. 117-118.

Братусь Б. С. К проблеме человека в психологии. Вопросы психологии. 1997. № 5. С. 3-19.

Бригадир М. Б. Організаційно-діяльнісні ігри в системі підготовки фахівців-професіоналів. Проблели елпіричних досліджень в психологіï. Київ : Гнозис, 2013. Вип. 7. С. 433-438.

Брушлинский А. В. Психология субъекта. Санкт Петербург : Алетейя, 2003. 272 c.

Бугерко Я. М. Психологічна динаміка розгортання рефлексивних процесів у модульно-розвивальному освітньому циклі: дис. ... канд. психол. наук: 19.00.07. Одеса, 2009. 255.

Булах І. С., Долинська Л. В. Психологічні аспекти міжособистісної взаємодії викладачів і студентів: навч.-метод. посіб. Київ : НПУ ім. М. П. Драгоманова, 2002. 114 с.

Велитченко Л. К. Педагогічна взаємодія як аналогова модель психологічного супроводу. Науковий вісник Південноукраӥнського націо-

(C) Furman (Humeniuk) Oksana, Hirnyak Andriy

DOI (article): https://doi.org/10.32626/2227-6246.2020-50.236-266 
нального педагогічного університету іл. К. Д. Уиинського. 2013. № 7-8. С. 136-145.

Гірняк А. Н. Психологічна діагностика міжособистісної взаємодії засобами соціометричного опитування. Психологія $і$ суспільство. 2019. № 3-4. С. 138-147.

Гірняк А. Психологічний аналіз і систематика стилів освітньої взаємодії. Психологія і суспільство. 2018. № 1-2. С. 118-126.

Гірняк Г., Гірняк А. Принципи психологічного проектування змісту і структури навчально-книжкових комплексів для студентів ВНЗ. Психологія і суспільство. 2014. № 1. С. 91-106.

Гозман Л. Я., Кроз М. В., Латинская М. В. Самоактуализационный тест. Москва : Роспедагентсов, 1995. 44 с.

Гуменюк О. Є. Модульно-розвивальне навчання: соціально-психологічний аспект / за ред. А. В. Фурмана. Київ : Школяр, 1998. 112 с.

Гуменюк О. Інноваційно-психологічний клімат як об'єкт теоретико-методологічного аналізу. Психологія і суспільство. 2007. № 1. С. 86108.

Демків В. Г. Психологічні особливості розвитку творчого мислення у майбутніх дизайнерів. Науковий огляд. 2019. Т. 6, № 59. С. 111127.

Зязюн I. А. Освітні парадигми та педагогічні технології у вимірах філософії освіти. Науковий вісник Миколаӥвського державного університету ілені В. О. Сухоллинського. Серія: Педагогічні науки. 2011. Вип. 1.33. С. 22-27.

Каленський А. А. Етика та мораль в діяльності майбутніх викладачів вищих навчальних закладів. Вісник Національного університету оборони України. 2013. Вип. 5. С. 38-42.

Кан-Калик В. А. Учителю о педагогическом общении: книга для учителя. Москва : Просвещение, 1987. 190 с.

Костін Я. Умови модульно-розвивальної взаємодії вчителя і учнів засобами інноваційного забезпечення. Психологія і суспільство. 2007. № 2. С. 57-68.

Леонтьев А. А. Психология общения. 2-е изд., испр. и доп. Москва : Смысл, 1997. 365 с.

Матвієнко О. В. Теоретичні аспекти забезпечення педагогічної взаємодії у навчально-виховному процесі школи. Наукові записки Тернопільського національного педагогічного університету ілені Володилира Гнатюка. Серія: Педагогіка. 2010. № 3. С. 3-8.

Надвинична Т. Л. Розвиток аналітико-синтетичної діяльності майбутніх соціальних працівників за допомогою системи навчальних проблемно-евристичних задач. Вісник Національної акаделиї Дер-

(C) Furman (Humeniuk) Oksana, Hirniak Andriy DOI (article): https://doi.org/10.32626/2227-6246.2020-50.236-266 
DOI: https://doi.org/10.32626/2227-6246.2020-50 2020. випуск 50

жавної прикордонної служби України. Серія: Психологічні науки. 2012. Вип. 3.

Педагогічна комунікація та ідентичність педагога: монографія / Г. О. Балл та ін.; за наук. ред. В. Л. Зливкова. Київ : Педагогічна думка, 2011. 160 с.

Ребуха Л. Історіогенез соціогуманітарної експертизи. Вітакультурний млин. 2011. Мод. 10. С. 34-37.

Ревасевич I. С. Особистісна адаптованість як багатопараметричне психодуховне утворення. Психологія $і$ суспільство. 2018. № 3-4. С. $132-145$.

Рибалка В. В. Особистісний підхід у профільному навчанні старшокласників: монографія / за ред. Г. О. Балла. Київ : Деміур, 1998. 160 с.

Рогов Е. И. Психология общения. Москва : Владос, 2004. 336 с.

Роджерс К. Клиент-центрированная психотерапия. Теория, современная практика и применение / пер. с англ. Т. Рожковой; под. ред. С. Римского. Москва : Психотерапия, 2007. 560 с.

Скрипник М. Вступ до теорії інтерактивних технологій післядипломного навчання. Післядиплолна освіта в Україні. 2012. № 2. С. 8791.

Фурман А. А. Ціннісно-орієнтаційні чинники особистісного розвитку майбутніх психологів: автореф. дис. ... канд. психол. наук: 19.00.07. Одеса, 2009. 20 с.

Фурман А. В., Гірняк Г. С., Козлова Т. В. Проектування змісту і структури електронного навчально-книжкового комплексу для учнів початкової школи. Вітакультурний млин. 2014. Модуль 16. C. 29-39.

Фурман А. В. Методологічна рефлексія генезису поняття про змістовий модуль. Вітакультурна методологія: антологія. До 25-річчя наукової школи професора А. В. Фурлана: колективна монографія. Тернопіль : ТНЕУ, 2019. С. 330-349.

Фурман А. В. Модульно-розвивальне навчання: принципи, умови, забезпечення: монографія. Київ : Правда Ярославичів, 1997. 340 с.

Фурман А. Розвивальна діагностика психологічної грамотності педагога. Тест «Хто підніме папірець?». Психологія і суспільство. 2002. № 1 (7). С. 119-153.

Фурман (Гуменюк) О. Є. Теорія і методологія інноваційно-психологічного клімату загальноосвітнього закладу: монографія. Ялта - Тернопіль : Підручники і посібники, 2008. 340 с.

Фурман О. Є. Психологічні параметри інноваційно-психологічного клімату загальноосвітнього навчального закладу: дис. ... д-ра психол. наук: 19.00.07. Одеса, 2015. 467 с.

(C) Furman (Humeniuk) Oksana, Hirnyak Andriy DOI (article): https://doi.org/10.32626/2227-6246.2020-50.236-266 http://journals.uran.ua/index.php/2227-6246 
Шандрук С. К. Організаційно-діяльнісна гра як засаднича умова і чинник розвитку професійних творчих здібностей і креативності майбутніх психологів. Вісник Національного університету оборони Украӥни. Київ : НУОУ, 2015. Вип. 2 (45). С. 291-300.

Шаюк О. Вітакультурні обрії сутнісного пізнання толерантності. Психологія і суспільство. 2017. № 1. С. 73-78.

Штепа О. Г. Дидактична взаємодія в системі вивчення педагогічних дисциплін у ВНЗ. Витоки педагогічної майстерності. Сер.: Педагогічні науки. 2011. Вип. 8 (1). С. 326-332.

Boller, Sharon, \& Kapp, Karl M. (2017). Play to Learn: Everything You Need to Know About Designing Effective Learning Games. Association for talent development.

Burkhanova, I., Drandrov, G., Ivanova, S., Stafeeva, A., Vorobyov, N., Balchugov, V., \& Ignatyeva, E. (2020). Technological Support of Professional Self-Development of Teachers in the System of Lifelong Learning. International Journal of Applied Exercise Physiology. Vol. 9, № 4. P. 117-124.

Knysh, O., Liaska, O., Bielinska, I., Levandovska, I., \& Vasylieva, O. (2020). Strategies in Planning Research Integrity Training (Evidence of Ukraine). Independent Journal of Management and Production. Vol. 11, № 8. P. 556-570.

Luterbach, J. Kenneth (2018). Designing and Developing Robust Instructional Apps. Routledge.

Lypka, M. (2018). Peculiarities of the mutually caused development of personality self-consciousness and Self-concept. Психологія $і$ суспільство. № 3-4. С. 154-162.

Maicon da Silva, Luis Carlos Alves da Silva, \& Flavio Regio Brambilla (2020). Value Co-Creation: a Study of Life Quality at an University in the South Brazil. Independent Journal of Management and Production. Vol. 11, № 3. P. 807-832.

Nilson, B. Linda (2016). Teaching at Its Best: A Research-based Resource for College Instructors. Jossey-Bass.

\section{References}

Amonashvili, Sh. A. (1996). Razmyshleniia o gumannoi pedagogike [Reflections on humane pedagogy]. Moskva : Izdatelskii dom Shalvy Amonashvili [in Russian].

Andrieiev, V. (2019). Pedahohichna vzaiemodiia vykladachiv koledzhu mystetskoho napriamku [Pedagogical interaction of teachers of the art college]. Social work and education, 6, 1, 80-86 [in Ukrainian].

(C) Furman (Humeniuk) Oksana, Hirniak Andriy

DOI (article): https://doi.org/10.32626/2227-6246.2020-50.236-266 
Babanskii, Yu. K. (1989). Izbrannyie pedagogicheskiie trudy [Selected pedagogical works]. Moskva : Pedagogika [in Russian].

Bekh, I. (2012). Aktsenty mystetskoi tvorchosti ta vykhovannia osobystosti [Accents of artistic creativity and education of personality]. Estetyka i etyka pedahohichnoi dii - Aesthetics and ethics of pedagogical action, 3, 38-43 [in Ukrainian].

Bekh, I. D. (1998). Osobystisno zoriientovane vykhovannia [Personally oriented education]. Kyiv : IZMN [in Ukrainian].

Bibler, V. (2015). Dialoh kultur. Filosofiia [Dialogue of cultures. Philosophy]. Psykholohiia i suspilstvo - Psychology and society, 3, 117-118 [in Ukrainian].

Bratus, B. S. (1997). K probleme cheloveka v psikhologii [The problem of man in psychology]. Voprosy psikhologii - Psychology issues, 5, 3-19 [in Russian].

Brushlinskii, A. V. (2003). Psikhologiia subiekta [Subject Psychology]. Sankt-Peterburg : Aleteiia [in Russian].

Bryhadyr, M. B. (2013). Orhanizatsiino-diialnisni ihry v systemi pidhotovky fakhivtsiv-profesionaliv [Organizational and activity games in the system of training professionals]. Problemy empirychnykh doslidzhen $v$ psykholohii - Problems of empirical research in psychology, 7, 433-438 [in Ukrainian].

Buherko, Ya. M. (2009). Psykholohichna dynamika rozhortannia refleksyvnykh protsesiv u modulno-rozvyvalnomu osvitnomu tsykli [Psychological dynamics of development of reflexive processes in the modular-developmental educational cycle]. Candidate's thesis. Odesa [in Ukrainian].

Bulakh, I. S., \& Dolynska, L. V. (2002). Psykholohichni aspekty mizhosobystisnoi vzaiemodii vykladachiv i studentiv [Psychological aspects of interpersonal interaction of teachers and students]. Kyiv : NPU im. M. P. Drahomanova [in Ukrainian].

Velytchenko, L. K. (2013). Pedahohichna vzaiemodiia yak analohova model psykholohichnoho suprovodu [Pedagogical interaction as an analog model of psychological support]. Naukovyi visnyk Pivdennoukrainskoho natsionalnoho pedahohichnoho universytetu im. K. D. Ushynskoho - Scientific Bulletin of the South Ukrainian National Pedagogical University named after K. D. Ushynsky, 7-8, 136-145 [in Ukrainian].

Hirnyak, A. N. (2019). Psykholohichna diahnostyka mizhosobystisnoi vzaiemodii zasobamy sotsiometrychnoho opytuvannia [Psychological diagnostics of interpersonal interaction by means of sociometric survey]. Psykholohiia i suspilstvo - Psychology and society, 3-4, 138-147 [in Ukrainian].

(C) Furman (Humeniuk) Oksana, Hirnyak Andriy

DOI (article): https://doi.org/10.32626/2227-6246.2020-50.236-266 
Hirnyak, A. (2018). Psykholohichnyi analiz i systematyka styliv osvitnoi vzaiemodii [Psychological analysis and systematics of educational interaction styles]. Psykholohiia i suspilstvo - Psychology and society, 1-2, 118-126 [in Ukrainian].

Hirnyak, H., \& Hirnyak, A. (2014). Pryntsypy psykholohichnoho proektuvannia zmistu i struktury navchalno-knyzhkovykh kompleksiv dlia studentiv VNZ [Principles of psychological design of the content and structure of educational book complexes for university students]. Psykholohiia $i$ suspilstvo - Psychology and society, 1, 91-106 [in Ukrainian].

Gozman, L. Ya., Kroz, M. V., \& Latinskaia, M. V. (1995). Samoaktualizatsionnyi test [Self-actualization test]. Moskva : Rospedagentsov [in Russian].

Humeniuk, O. (2007). Innovatsiino-psykholohichnyi klimat yak obiekt teoretyko-metodolohichnoho analizu [Innovative psychological climate as an object of theoretical and methodological analysis]. Psykholohiia i suspilstvo - Psychology and society, 1, 86-108 [in Ukrainian].

Humeniuk, O. Ye. (1998). Modulno-rozvyvalne navchannia: sotsialno-psykholohichnyi aspekt [Modular and developmental learning: socio-psychological aspect]. Kyiv : Shkoliar [in Ukrainian].

Demkiv, V. H. (2019). Psykholohichni osoblyvosti rozvytku tvorchoho myslennia $u$ maibutnikh dyzaineriv [Psychological features of the development of creative thinking in future designers]. Naukovyi ohliad - Scientific review, 6, 59, 111-127 [in Ukrainian].

Ziaziun, I. A. (2011). Osvitni paradyhmy ta pedahohichni tekhnolohii $\mathrm{u}$ vymirakh filosofii osvity [Educational paradigms and pedagogical technologies in the dimensions of the philosophy of education]. Naukovyi visnyk Mykolaivskoho derzhavnoho universytetu imeni V. O. Sukhomlynskoho. Seriia: Pedahohichni nauky - Scientific Bulletin of Mykolayiv State University named after V. O. Sukhomlynsky. Series: Pedagogical sciences, 1, 33, 22-27 [in Ukrainian].

Kalenskyi, A. A. (2013). Etyka ta moral v diialnosti maibutnikh vykladachiv vyshchykh navchalnykh zakladiv [Ethics and morality in the activities of future teachers of higher educational institutions]. Visnyk Natsionalnoho universytetu oborony Ukrainy - Bulletin of the National University of Defense of Ukraine, 5, 38-42 [in Ukrainian].

Kan-Kalik, V. A. (1987). Uchiteliu o pedagogicheskom obshchenii [For the teacher about pedagogical communication]. Moskva : Prosveshcheniie [in Russian].

Kostin, Ya. (2007). Umovy modulno-rozvyvalnoi vzaiemodii vchytelia i uchniv zasobamy innovatsiinoho zabezpechennia [Conditions of mo-

(C) Furman (Humeniuk) Oksana, Hirniak Andriy DOI (article): https://doi.org/10.32626/2227-6246.2020-50.236-266 
DOI: https://doi.org/10.32626/2227-6246.2020-50 2020. випуск 50

dular-developmental interaction of teachers and students by means of innovative support]. Psykholohiia $i$ suspilstvo - Psychology and society, 2, 57-68 [in Ukrainian].

Leontiev, A. A. (1997). Psikhologiia obshcheniia [Communication psychology]. Moskva : Smysl [in Russian].

Matviienko, O. V. (2010). Teoretychni aspekty zabezpechennia pedahohichnoi vzaiemodii u navchalno-vykhovnomu protsesi shkoly [Theoretical aspects of providing pedagogical interaction in the educational process of the school]. Naukovi zapysky Ternopilskoho natsionalnoho pedahohichnoho universytetu imeni Volodymyra Hnatiuka. Seriia: Pedahohika - Scientific notes of Ternopil Volodymyr Hnatiuk National Pedagogical University. Series: Pedagogy, 3, 3-8 [in Ukrainian].

Nadvynychna, T. L. (2012). Rozvytok analityko-syntetychnoi diialnosti maibutnikh sotsialnykh pratsivnykiv za dopomohoiu systemy navchalnykh problemno-evrystychnykh zadach [Development of analytical-synthetic activity of future social workers with the help of a system of educational problem-heuristic tasks]. Visnyk Natsionalnoi akademii Derzhavnoi prykordonnoi sluzhby Ukrainy. Seriia: Psykholohichni nauky - Bulletin of the National Academy of the State Border Guard Service of Ukraine. Series: Psychological Sciences, 3 [in Ukrainian].

Ball, H. O. (2011). Pedahohichna komunikatsiia ta identychnist pedahoha [Pedagogical communication and teacher identity]. Kyiv : Pedahohichna dumka [in Ukrainian].

Rebukha, L. (2011). Istoriohenez sotsiohumanitarnoi ekspertyzy [Historiogenesis of socio-humanitarian examination]. Vitakulturnyi mlyn Vitacultural mill, 10, 34-37 [in Ukrainian].

Revasevych, I. S. (2018). Osobystisna adaptovanist yak bahatoparametrychne psykhodukhovne utvorennia [Personal adaptability as a multiparametric psycho-spiritual education]. Psykholohiia i suspilstvo Psychology and society, 3-4, 132-145 [in Ukrainian].

Rybalka, V. V. (1998). Osobystisnyi pidkhid u profilnomu navchanni starshoklasnykiv [Personal approach in the profile education of senior students]. Kyiv : Demiur [in Ukrainian].

Rogov, E. I. (2004). Psikhologiia obshcheniia [Communication psychology]. Moskva : Vlados [in Russian].

Rogers, K. (2007). Klient-tsentrirovannaia psikhoterapia. Teoriia, sovremennaia praktika i primeneniie [Client-centered psychotherapy. Theory, modern practice and application]. Moskva : Psikhoterapiia [in Russian].

(C) Furman (Humeniuk) Oksana, Hirnyak Andriy

DOI (article): https://doi.org/10.32626/2227-6246.2020-50.236-266 
Skrypnyk, M. (2012). Vstup do teorii interaktyvnykh tekhnolohii pisliadyplomnoho navchannia [Introduction to the theory of interactive technologies of postgraduate education]. Pisliadyplomna osvita v Ukraini - Postgraduate education in Ukraine, 2, 87-91 [in Ukrainian].

Furman, A. A. (2009). Tsinnisno-oriientatsiini chynnyky osobystisnoho rozvytku maibutnikh psykholohiv [Value-oriented factors of personal development of future psychologists]. Extended abstract of candidate's thesis. Odesa [in Ukrainian].

Furman, A. V., Hirnyak, H. S., \& Kozlova, T. V. (2014). Proektuvannia zmistu i struktury elektronnoho navchalno-knyzhkovoho kompleksu dlia uchniv pochatkovoi shkoly [Designing the content and structure of the electronic educational and book complex for primary school students]. Vitakulturnyi mlyn - Vitacultural mill, 16, 29-39 [in Ukrainian].

Furman, A. V. (2019). Metodolohichna refleksiia henezysu poniattia pro zmistovyi modul [Methodological reflection on the genesis of the concept of semantic module]. Vitakulturna metodolohiia: antolohiia. Do 25-richchia naukovoi shkoly profesora A. V. Furmana - Vitacultural methodology: anthology. To the 25th anniversary of the scientific school of professor A. V. Furman, (pp. 330-349). Ternopil : TNEU [in Ukrainian].

Furman, A. V. (1997). Modulno-rozvyvalne navchannia: pryntsypy, umovy, zabezpechennia [Modular and developmental learning: principles, conditions, support]. Kyiv : Pravda Yaroslavychiv [in Ukrainian].

Furman, A. (2002). Rozvyvalna diahnostyka psykholohichnoi hramotnosti pedahoha. Test «Khto pidnime papirets?» [Developmental diagnosis of psychological literacy of a teacher. Test «Who will pick up the paper?»]. Psykholohiia i suspilstvo - Psychology and society, 1, 119-153 [in Ukrainian].

Furman (Humeniuk), O. Ye. (2008). Teoriia i metodolohiia innovatsiinopsykholohichnoho klimatu zahalnoosvitnoho zakladu [Theory and methodology of innovation and psychological climate of a secondary school]. Yalta - Ternopil : Pidruchnyky i posibnyky [in Ukrainian].

Furman, O. Ye. (2015). Psykholohichni parametry innovatsiino-psykholohichnoho klimatu zahalnoosvitnoho navchalnoho zakladu [Theory and methodology of innovation and psychological climate of a secondary school]. Doctor's thesis. Odesa [in Ukrainian].

Shandruk, S. K. (2015). Orhanizatsiino-diialnisna hra yak zasadnycha umova i chynnyk rozvytku profesiinykh tvorchykh zdibnostei i kreatyvnosti maibutnikh psykholohiv [Organizational and activity

(C) Furman (Humeniuk) Oksana, Hirniak Andriy DOI (article): https://doi.org/10.32626/2227-6246.2020-50.236-266 
game as a basic condition and factor of development of professional creative abilities and creativity of future psychologists]. Visnyk $\mathrm{Na}$ tsionalnoho universytetu oborony Ukrainy - Bulletin of the National University of Defense of Ukraine, 2 (45), 291-300 [in Ukrainian].

Shaiuk, O. (2017). Vitakulturni obrii sutnisnoho piznannia tolerantnosti [Vitacultural horizons of essential knowledge of tolerance]. Psykholohiia i suspilstvo - Psychology and society, 1, 73-78 [in Ukrainian].

Shtepa, O. H. (2011). Dydaktychna vzaiemodiia v systemi vyvchennia pedahohichnykh dystsyplin u VNZ [Didactic interaction in the system of studying pedagogical disciplines in higher education]. Vytoky pedahohichnoi maisternosti. Ser.: Pedahohichni nauky - The origins of pedagogical skills. Series: Pedagogical sciences, 8 (1), 326-332 [in Ukrainian].

Boller, Sharon, \& Kapp, Karl M. (2017). Play to Learn: Everything You Need to Know About Designing Effective Learning Games. Association for talent development.

Burkhanova, I., Drandrov, G., Ivanova, S., Stafeeva, A., Vorobyov, N., Balchugov, V., \& Ignatyeva, E. (2020). Technological Support of Professional Self-Development of Teachers in the System of Lifelong Learning. International Journal of Applied Exercise Physiology, 9, 4, 117-124.

Knysh, O., Liaska, O., Bielinska, I., Levandovska, I., \& Vasylieva, O. (2020). Strategies in Planning Research Integrity Training (Evidence of Ukraine). Independent Journal of Management and Production, 11, 8, 556-570.

Luterbach, J. Kenneth. (2018). Designing and Developing Robust Instructional Apps. Routledge.

Lypka, M. (2018). Peculiarities of the mutually caused development of personality self-consciousness and Self-concept. Psykholohiia $i$ suspilstvo - Psychology and society, 3-4, 154-162.

Maicon da Silva, Luis Carlos Alves da Silva, \& Flavio Regio Brambilla (2020). Value Co-Creation: a Study of Life Quality at University in the South Brazil. Independent Journal of Management and Production, 11, 3, 807-832.

Nilson, B. Linda. (2016). Teaching at Its Best: A Research-based Resource for College Instructors. Jossey-Bass.

Фурман (Гуменюк) Оксана, Гірняк Андрій. Психологічна компетентність викладача як передумова ефективної розвивальної взаємодії зі студентами

(C) Furman (Humeniuk) Oksana, Hirnyak Andriy

DOI (article): https://doi.org/10.32626/2227-6246.2020-50.236-266 http://journals.uran.ua/index.php/2227-6246 


\section{АНОТАЦІЯ}

Meта cmammi - теоретично обгрунтувати й емпірично довести, що рівень психологічної компетентності викладачів-дослідників значно впливає на якість організації та ефрективність повноцінної розвивальної взаємодії зі студентами в умовах сучасного зВО.

Методи. У ході дослідження автори послуговувалися теоретичними способами пізнання (критичний аналіз, теоретичний синтез, ранжування, абстрагування, критеріальне порівняння, методологічне узагальнення, теоретичне моделювання тощо), а також емпіричними методами фріксації фрактологічних даних (закрите анкетування, психолого-педагогічний експеримент, психодіагностичні методики: опитувальник А. Фурмана "Хто підніме папірець?», самоактуалізаційний тест (САT) Е. Шострома тощо). В експерименті, котрий тривав із вересня 2017 по вересень 2019 рр., взяли участь 65 викладачів і 511 студентів бакалаврату (I-IV курсів) юридичного факультету Тернопільського національного економічного університету (ТНЕУ).

Результати дослідження. Окреслено актуальні завдання й інновачійні шляхи вдосконалення психологічної підготовки викладачів сучасних ЗВО, зокрема розкрито авторський досвід реалізації програми підготовки викладача-психолога-дослідника (690 год.), що супроводжується нарощуванням експериментальних умов у інноваційній діяльності педагогічного колективу; охарактеризовано п'ять груп експериментальних змін (нововведень), що спричинили позитивну перебудову внутрішнього світу педагогів-дослідників; експериментально відстежено динаміку зростання психологічної компетентності викладачів юридичного фракультету THЕУ за два роки фундаментального експерименту; емпірично обгрунтовано зростання сукупного коефріцієнта самоактуалізації педагогів-дослідників за 13-ма шкалами вимірювання. Одержані кількісні показники наочно переконують у тому, що за два роки фундаментального експериментування суттєво зросли як сумарний показник коефіцієнта самоактуалізації педагогічного колективу факультету (від 43,2\% до 48,8\%), так і його структурні складові (контактність - 9\%, самоприйняття - 7,7\%, гнучкість поведінки - 7,5\%, синергійність - 7,3\%, сенситивність - 6,2\%, спонтанність - 6,0\% тощо). Особливо позитивним $\epsilon$ факт посилення тенденцій до самореалізації викладачів за базовими шкалами - часової компетентності й підтримки, сумарне зростання котрих становить $15,6 \%$.

(C) Furman (Humeniuk) Oksana, Hirniak Andriy DOI (article): https://doi.org/10.32626/2227-6246.2020-50.236-266 
Висновки. Модульно-розвивальна система навчання має низку переваг, порівняно з класичною академічною системою. Зокрема, вона уможливлює підготовку викладача до професійної діяльності з психолого-педагогічним змістом актуального освітнього процесу й за допомогою відповідних технологій дає змогу грунтовніше втілювати в практику сучасного ЗВО полірівневу розвивальну взаємодію зі студентами. Ефективність останньої першочергово залежить від психологічної грамотності викладача, гуманізації завдань, змісту і стилю освітньої діяльності й утілення оригінальних технологій ведення цілісного модульно-розвивального процесу. Якісно вищої професійно-психологічної підготовки викладача можна домогтися, коли центром навчального процесу $є$ не зміст предмета, а взаємодія наставника і студента, яка не лише гуманізує освітнє середовище, а й передбачає зміну власної позиції кожного суб'єкта актуальних взаємин. При цьому інтегральним психометричним показником розвитку культури і функціональної грамотності викладачів-дослідників $\epsilon$ коедріцієнт самоактуалізації, зростання якого вказує на суттєве розширення меж конструктивного вияву свободи, альтруїзму, творчості, самоповаги, взаєморозуміння і взаємоприйняття особистостей в індивідуально зорієнтованому освітньому процесі.

Ключові слова: модульно-розвивальна система, психологічна компетентність, розвивальна взаємодія, соціально-психологічний експеримент, етапи навчального модуля, самоактуалізована особистість.

\section{Фурман (Гуменюк) Оксана, Гирняк Андрей. Психологическая компетент- ность преподавателя как предпосылка эффективного развивающего взаимодействия со студентами}

\section{АННОТАЦИЯ}

Цель статьи - теоретически обосновать и эмпирически доказать, что уровень психологической компетентности преподавателей-исследователей значительно влияет на качество организации и эфрективность полноценного развивающего взаимодействия со студентами в условиях современного ЗВО.

Методы. В ходе исследования авторы пользовались теоретическими способами познания (критический анализ, теоретический синтез, ранжирование, абстрагирование, критериальное сравнение, методологическое обобщение, теоретическое моделирование и т. д.), а также (c) Furman (Humeniuk) Oksana, Hirnyak Andriy

DOI (article): https://doi.org/10.32626/2227-6246.2020-50.236-266 http://journals.uran.ua/index.php/2227-6246 
эмпирическими методами фиксации фрактологических данных (закрытое анкетирование, психолого-педагогический эксперимент, психодиагностические методики: опросник А. Фурмана "Кто поднимет бумажку?», самоактуализационный тест (САT) Э. Шострома и т. д.). В эксперименте, который длился с сентября 2017 по сентябрь 2019 г2., приняли участие 65 преподавателей и 511 студентов бакалаврата (I-IV курсов) юридического факультета Тернопольского национального экономического университета (ТНЭУ).

Результаты исследования. Определены актуальные задачи и инновационные пути совершенствования психологической подготовки преподавателей современных 3ВО, в частности раскрыт авторский опыт реализации программы подготовки преподавателя-психолога-исследователя (690 ч.), что сопровождается наращиванием экспериментальных условий в инновационной деятельности педагогического коллектива; охарактеризованы пять групп экспериментальных изменений (нововведений), которые вызвали положительную перестройку внутреннего мира педагогов-исследователей; экспериментально отслежена динамика роста психологической компетентности преподавателей юридического факультета ТНЭУ за два года фундаментального эксперимента; эмпирически обоснован рост совокупного коэффициента самоактуализации педагогов-исследователей по 13-и икалам измерения. Полученные количественные показатели наглядно убеждают в том, что за два года фундаментального экспериментирования существенно выросли как суммарный показатель коэффициента самоактуализации педагогического коллектива факультета (от 43,2\% до 48,8\%), так и его структурные составляющие (контактность - 9\%, самопринятие - 7,7\%, гибкость поведения - 7,5\%, синергичность - 7,3\%, сензитивность - 6,2\%, спонтанность -6,0\% и т. д.). Особенно положительным является факт усиления тенденций к самореализации преподавателей по базовым шкалам - временной компетентности и поддержки, суммарный рост которых составляет 15,6\%.

Выводы. Модульно-развивающая система обучения имеет ряд преимуществ, по сравнению с классической академической системой. В частности, она дает возможность осуществлять подготовку преподавателя к профессиональной деятельности с психолого-педагогическим содержанием актуального образовательного процесса и с помощью соответствующих технологий способствует основательному воплощению

(C) Furman (Humeniuk) Oksana, Hirniak Andriy DOI (article): https://doi.org/10.32626/2227-6246.2020-50.236-266 
DOI: https://doi.org/10.32626/2227-6246.2020-50

в практику современного ЗВО полиуровневого развивающего взаимодействия со студентами. Эфрфективность последнего, в первую очередь, зависит от психологической грамотности преподавателя, гуманизации задач, содержания и стиля образовательной деятельности и воплощения оригинальных технологий ведения целостного модульно-развивающего процесса. Качественно высшей профессионально-психологической подготовки преподавателя можно добиться, когда иентром учебного процесса является не содержание предмета, а взаимодействие наставника и студента, которое не только гуманизирует образовательную среду, но и предусматривает изменение собственной позиции каждого субъекта актуальных взаимоотношений. При этом интегральным психометрическим показателем развития культуры и функциональной грамотности преподавателей-исследователей является коэффициент самоактуализации, рост которого указывает на существенное расиирение грании конструктивного проявления свободы, альтруизма, творчества, самоуважения, взаимопонимания и взаимопринятия личностей в индивидуально ориентированном образовательном процессе.

Ключевые слова: модульно-развивающая система, психологическая компетентность, развивающее взаимодействие, социально-психологический эксперимент, этапы учебного модуля, самоактуализированная личность.

Original manuscript received June 14, 2020

Revised manuscript accepted July 23, 2020

(C) Furman (Humeniuk) Oksana, Hirnyak Andriy

DOI (article): https://doi.org/10.32626/2227-6246.2020-50.236-266 http://journals.uran.ua/index.php/2227-6246 